\section{Australian Journal of Crop Science}

AJCS 15(02):278-283 (2021)

doi: 10.21475/ajcs.21.15.02.p2984

\title{
Postharvest conservation of Tommy atkins mango fruits during storage using Moringa oleifera oil-based coating
}

\author{
Semirames Silva ${ }^{1 *}$, Ana Paula Sousa ${ }^{1}$, Josivanda Gomes ${ }^{1}$, Romário Andrade ${ }^{1}$, Gustavo Lima ${ }^{1}$, Eliezer \\ Siqueira ${ }^{2}$, Wilton Silva ${ }^{1}$, Cleide Silva e Silva ${ }^{1}$, Francisco Filho $^{2}$, Ana Regina Campos ${ }^{1}$ \\ ${ }^{1}$ Agricultural Engineering Department, Federal University of Campina Grande, Paraiba, 58428-830, Brazil \\ ${ }^{2}$ Agroecology Department, Federal Institute of Paraiba, Sousa Campus, Sousa, Paraiba, 58805-345, Brazil
}

\author{
*Corresponding author: semirames.agroecologia@gmail.com
}

\begin{abstract}
Among several biodegradable coatings used to extend the shelf life of fresh fruits, those that can be obtained from Moringa oleifera stand out due to their extraordinary biochemical, antibacterial and antifungal properties. Another aspect is their constitution which is composed of proteins, lipids, carbohydrates, carotenoids, vitamins, minerals and natural bioactive compounds, that can be applied for the development of functional foods due to their nutritional and pharmaceutical properties. The objective of this study was to evaluate the effect of bio-based coating produced from different concentrations of Moringa oleifera seed oil added to cassava starch in the postharvest conservation of Tommy atkins mango fruits. The bio-based coating was applied to mango fruits stored at room temperature $\left(27^{\circ} \mathrm{C}\right)$ for 15 days. Mangoes were submitted to the following treatments: moringa oil (Moringa oleifera) in 4 concentrations: $0.5 \%(\mathrm{v} / \mathrm{v})+$ cassava starch; $1 \%(\mathrm{v} / \mathrm{v})+$ cassava starch; $1.5 \%(\mathrm{v} / \mathrm{v})+$ cassava starch and a control treatment without coating (0\%), during 15 days of storage $(0,3,6,9,12$ and 15 days), adding up to 24 treatments with three replications. The application of moringa-oil-based coating prolonged the postharvest shelf life of the Tommy atkins mango by maintaining the physicochemical and physical properties during 12 days of storage at room temperature when compared to control treatment. $M$. oleifera oil-based coatings delayed the degradation of the pigments, making the bio-coated fruits gain shine and remain with it.
\end{abstract}

Keywords: Antimicrobial activity; Biodegradable; Biofilm; Moringa oil; Food packaging.

Abbreviations: $M$. oleifera_Moringa oleifera, TSS_total soluble solids, TTA_total titratable acidity, L. monocytogenes_Listeria monocytogenes, S. aureus_Staphylococcus aureus, ppm_Parts per million, v/v_volume by volume.

\section{Introduction}

The Brazilian semiarid region has remarkable irrigated agriculture, especially with banana, melon and mango crops. Quality aspects which are most demanded by consumers are appearance, taste and nutritional value (Sanches et al., 2017). According to Pereira et al. (2014) physical and physicochemical changes are the main causes of quality loss during storage. For this reason, adequate storage and the use of postharvest technology are necessary to preserve the quality of the fruits. The various methods currently used to reduce losses in the postharvest of fruits have demonstrated a satisfactory increase in their shelf life after reaching their final destination (Assis and Brito, 2014).

According to Pimentel et al. (2011), there are many techniques available for the postharvest conservation of fruits. However, the use of edible and biodegradable films, as well as bio-based coating have been gaining ground in this market, mainly as an alternative to reduce environmental impacts caused by plastic packaging. In addition, the treatment with chemical products has disadvantages as, for example, the use of fungicides which, besides producing residual effects, decreases the shelf life of the fruits. The use of edible coatings can interfere with the respiratory metabolism in fruits, creating a semipermeable barrier against the movement of oxygen, carbon dioxide, moisture and solute, thus controlling the exchange of humidity, gases and solutes with the environment (Lima et al., 2018). Some researchers carried out studies using natural coatings. Oliveira et al. (2018) applied natural coating on mango fruits, Onias et al. (2018) on guava and Xu et al. (2018) on tangerine.

Natural coatings have an abundance of raw materials, as they can be extracted from various sources of cereals, roots, seeds and tubers such as rice, wheat, corn, potatoes and cassava. These vegetables are available all over the world and present several possibilities for chemical, physical or genetic modification giving rise to resistant films and coatings (Mali et al., 2010). According to Zhao (2019), the use of edible coatings offers more benefits than synthetic materials in terms of biocompatibility, being non-toxic and having low cost. Edible coatings are formed from a suspension of a thickening agent, which forms a film around it after application and can be used as an alternative for preserving fruits, due to its ability to modify the atmosphere, to reduce respiration and transpiration rate, moisture, and also to maintain firmness and delay senescence of fruits (Mannozzi et al., 2017).

Plant-derived products have antimicrobial activity and induce resistance to pathogens. Moringa oleifera Lam., which is originally from India, is among the plants that have antimicrobial, antifungal and also preservative activity (Ghodsi et al., 2014). The search for alternative sources to 
supply the demand for vegetable oils has revealed that the lipid fraction obtained from co-products of the agribusiness, in particular from vegetable seeds, contains significant percentages of polyunsaturated fatty acids, which are recommended as dietary supplements because they reduce the incidence of high-risk inflammatory diseases in humans. The oil obtained from moringa seeds is an example.

Researchers have invested in the prospecting of $M$. oleifera seeds as a promising and low-cost alternative to reduce and/or eliminate undesirable microorganisms from an environmental, food or clinical point of view (Abalaka et al., 2012). Othman and Ahmed (2017) explain that bioactive compounds found in moringa have an antimicrobial role as they make changes in the cell wall and cell proteins of microorganisms. Based on the discussion above, the objective was to evaluate the effect of bio-based coating produced from different concentrations of Moringa oleifera seed oil added to cassava starch in the postharvest conservation of Tommy atkins mango fruits during storage.

\section{Results and discussion}

The mean values for the $\mathrm{pH}$ and total titratable acidity parameters are described in Table 1. There was a significant interaction $(\mathrm{P}<0.01)$ for the $\mathrm{pH}$ parameter. Therefore, the effects of $M$. oleifera seed oil concentrations on the $\mathrm{pH}$ of the fruits depend on the storage time. The reverse was observed for acidity ( $P>0.05$ ), as the effects of concentrations are independent of storage times. However, the storage times were significant $(P<0.01)$, thus, they have different effects on the acidity of the fruits. Oil concentrations have similar effects in relation to this parameter $(\mathrm{P}>0.05)$.

There was an increase in $\mathrm{pH}$ while the values of acidity decreased (Fig. 1). $R^{2}$ below $90 \%$ is observed, probably due to the high dispersion of the data. Mango is considered an acidic fruit for most cultivars as it presents $\mathrm{pH}$ values below 6 as obtained in this research. The pH obtained by Cruz et al. (2011) when evaluating the effect of moringa on the quality of Tommy Atkins mango fruits ranged from 3.7 for fruits treated with $M$. oleifera oil to 5.08 for fruits treated with tween 20.

Reduction in acidity is due to the content of organic acids that decreases with ripening in most tropical fruits, due to the use of these acids in the Krebs cycle as an energy source during the respiratory process and even as a carbon source for the synthesis of sugars (Chitarra and Chitarra, 2005). Mango pulp must comply with the characteristics and composition according to current legislation: minimum $\mathrm{pH}$ of 3.5; total acidity $0.3 \%$; minimum ${ }^{\circ}$ Brix of $11 \%$. Based on legislation, Tommy atkins mango fruits with moringa oil biobased coating presented $\mathrm{pH}$ and ${ }^{\circ}$ Brix within the limits allowed by Brazilian legislation for mango pulp (Brazil, 2000). The results obtained for total soluble solids (oBrix) and the relationship between total soluble solids and total titratable acidity (TSS/TTA) are shown in Table 2 . $^{\circ} \mathrm{Brix}$ and the TSS/TTA ratio of the fruits showed a significant effect $(P<0.01)$, thus, the effects of the concentrations of $M$. oleifera oil on these parameters depend on the storage time, as this depends on the concentrations of the oil. Concentrations of 0.5 and $1 \%$ showed the best results for both parameters studied, as they presented the highest mean values.

The taste of the fruits is given according to the TSS/TTA ratio. An increase in parameters was observed after the third day of storage, with a consequent reduction after 12 days, indicating that the moringa oil bio-based coating did not reduce the consumption of sugars during the respiratory process, maintaing them for up to 12 days.

Teodosio et al. (2018a), when studying papaya fruits covered with microalgae and gum arabic, observed that the content of soluble solids increased in all treatments during the storage period. The tendency of the TSS/TTA ratio is to increase with maturation due to the increase in TSS content and the decrease in TTA. This fact was observed in this research due to the degradation of polysaccharides and oxidation of acids in the cycle of tricarboxylic acids in respiration (Moreira, 2013).

The loss of fruit mass is related to the loss of water, inducing changes in appearance such as withering and wrinkling. For this parameter, there was significant interaction $(P<0.01)$, therefore, the effects of oil concentrations used in the production of bio-based coating on the loss of mango fruit mass depend on the storage period (Fig. 2).

Mass loss of fresh fruits increased gradually during the storage period, probably due to fact that water present in fruits migrate to the environment, possibly because of the transpiration of the stomata and direct evaporation through the epidermal cells (Kumar et al., 2017). However, bio-based coated fruits with 0.5 and $1 \%$ obtained minor differences in mass loss during storage, indicating that the $M$. oleifera seed oil bio-based coatings protected the fruits against excessive water loss. Onias et al. (2016), when analyzing mango fruits subjected to microalgae-based coatings, observed that mass loss increased in all treatments during the storage period. $\mathrm{R}^{2}$ greater than $99 \%$ is observed, evidencing that data fits to the regression model and indicating that the equation can be used to predict the results obtained.

Lin et al. (2019) produced nanofibers from M. oleifera and applied them to cheeses. The authors found that they had high antibacterial activity against $L$. monocytogenes and $S$. aureus at $4{ }^{\circ} \mathrm{C}$ and $25^{\circ} \mathrm{C}$ for 10 days, without any effect on organoleptic quality of the cheese. For the authors, all parts of the moringa have antibacterial activity. They also argue that nanofibers could be promising material in the development of packaging for food preservation. The treatments based on moringa seed oil do not present toxicity based on studies already conducted with the seed.

Cortez-Veja et al. (2013) evaluated papaya which was minimally processed using different coatings based on xanthan gum during 12 days of storage at $4{ }^{\circ} \mathrm{C}$. All treatments tested were effective in reducing mass loss, which were in the range of 6.03 and $5.30 \%$. The reverse was observed by Borges et al. (2012), when they found that strawberries coated with xanthan and sage essential oil showed positive results, avoiding a great loss of mass when compared to the control sample. Studies indicate that the vegetable species $M$. oleifera has active compounds in its composition, being more intense in oil, which promote a slower ripening, that is, they delay the maturation process (Cruz et al., 2011).

The peel color of mango fruits did not show significant interaction $(P>0.05)$ for the factors studied (Table 3 ). Variation in the color of the fruits was observed, especially for those in the control treatment without bio-based coating. Difference in the color of the fruit peel may have been caused by a peak in ethylene production, since such transformation is closely linked to ethylene biosynthesis, which promotes an increase in the activity of chlorophyllase enzymes responsible for chlorophyll degradation and 
Table 1. $\mathrm{pH}$ and TTA of Tommy atkins mango fruits during storage.

\begin{tabular}{|c|c|c|c|c|c|c|c|}
\hline \multirow[b]{2}{*}{ Parameter } & \multirow[b]{2}{*}{$\begin{array}{l}\text { Concentration } \\
\text { oil (\%) }\end{array}$} & \multicolumn{6}{|c|}{ Storage times (days) } \\
\hline & & 0 & 3 & 6 & 9 & 12 & 15 \\
\hline \multirow{4}{*}{$\mathrm{pH}$} & 0 (control) & $3.65^{\mathrm{aD}}$ & $4.85^{b c}$ & $4.94^{\mathrm{abc}}$ & $5.49^{\mathrm{a} A}$ & $5.24^{\mathrm{aB}}$ & $5.36^{\mathrm{aAB}}$ \\
\hline & 0.5 & $3.65^{\mathrm{ac}}$ & $5.14^{\mathrm{aAB}}$ & $5.06^{\mathrm{aB}}$ & $5.33^{\mathrm{abA}}$ & $5.25^{\mathrm{aAB}}$ & $5.20^{\mathrm{aAB}}$ \\
\hline & 1 & $3.65^{\mathrm{aD}}$ & $5.08^{\mathrm{aB}}$ & $4.86^{\mathrm{bC}}$ & $5.27^{\mathrm{bAB}}$ & $5.21^{\mathrm{aAB}}$ & $5.38^{\mathrm{aA}}$ \\
\hline & 1.5 & $3.65^{\mathrm{aD}}$ & $5.23^{\mathrm{aB}}$ & $4.87^{\mathrm{abc}}$ & $5.46^{\mathrm{abA}}$ & $5.28^{\mathrm{aAB}}$ & $5.32^{\mathrm{aAB}}$ \\
\hline \multirow{4}{*}{$\operatorname{TTA}(\%)^{1}$} & 0 (control) & $8.63^{\mathrm{aA}}$ & $2.99^{\mathrm{aB}}$ & $2.45^{\mathrm{aB}}$ & $1.93^{\mathrm{aB}}$ & $1.97^{\mathrm{aB}}$ & $1.78^{\mathrm{aB}}$ \\
\hline & 0.5 & $8.63^{\mathrm{aA}}$ & $2.17^{\mathrm{aB}}$ & $2.11^{\mathrm{aB}}$ & $1.72^{\mathrm{aB}}$ & $1.70^{\mathrm{aB}}$ & $1.73^{\mathrm{aB}}$ \\
\hline & 1 & $8.63^{\mathrm{aA}}$ & $3.60^{\mathrm{aB}}$ & $2.51^{\mathrm{aBC}}$ & $1.39^{\mathrm{aC}}$ & $2.02^{\mathrm{aBC}}$ & $1.69^{\mathrm{aC}}$ \\
\hline & 1.5 & $8.64^{\mathrm{aA}}$ & $2.07^{\mathrm{aB}}$ & $2.96^{\mathrm{aB}}$ & $1.79^{\mathrm{aB}}$ & $2.03^{\mathrm{aB}}$ & $1.99^{\mathrm{aB}}$ \\
\hline
\end{tabular}

Means followed by the same lowercase letter in the columns and uppercase in the rows do not differ statistically in the Tukey test at $5 \%$ probability. TTA ${ }^{1}$ : Total titratable acidity.
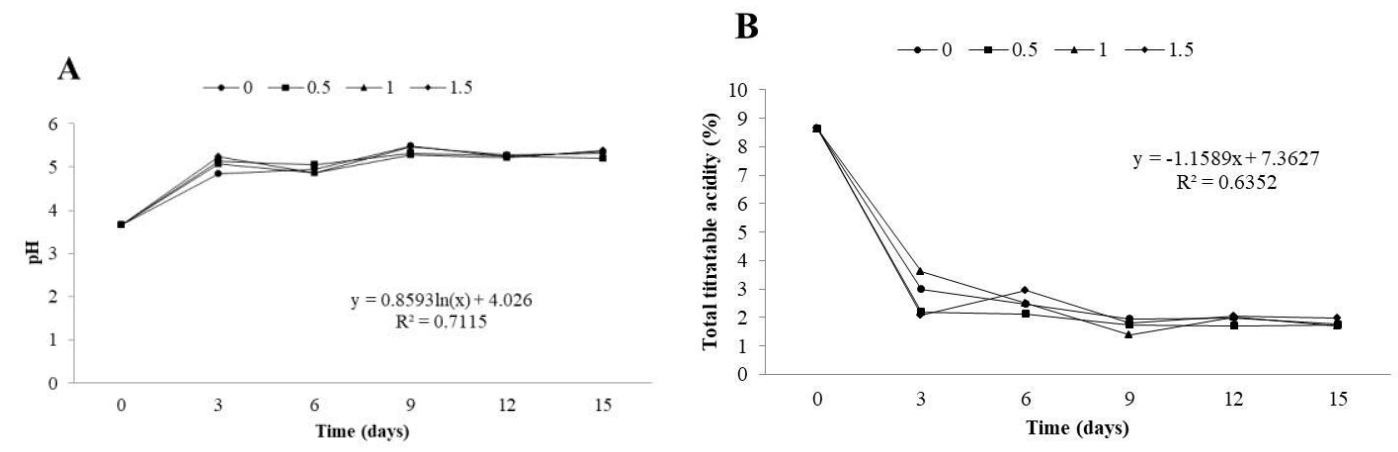

Fig 1. Graphical representation of $\mathrm{pH}(\mathrm{A})$ and total titratable acidity (B) of Tommy Atkins mango fruits during storage.

Table 2. ${ }^{\text {Brix }}$ and TSS/TTA ratio of bio-based coated Tommy Atkins mango fruits during storage.

\begin{tabular}{|c|c|c|c|c|c|c|c|}
\hline \multirow[b]{2}{*}{ Parameter } & \multirow[b]{2}{*}{$\begin{array}{l}\text { Concentration } \\
\text { oil (\%) }\end{array}$} & \multicolumn{6}{|c|}{ Storage times (days) } \\
\hline & & 0 & 3 & 6 & 9 & 12 & 15 \\
\hline \multirow{4}{*}{${ }^{\circ}$ Brix (\%) } & 0 (control) & $12.03^{\mathrm{aE}}$ & $15.17^{\mathrm{bA}}$ & $14.20^{\mathrm{CB}}$ & $14.00^{\mathrm{CB}}$ & $13.00^{\mathrm{cC}}$ & $12.40^{\mathrm{bD}}$ \\
\hline & 0.5 & $12.03^{\mathrm{aE}}$ & $16.47^{\mathrm{aA}}$ & $15.90^{\mathrm{aB}}$ & $15.40^{\mathrm{bC}}$ & $14.13^{\mathrm{aD}}$ & $13.40^{\mathrm{aE}}$ \\
\hline & 1 & $12.03^{\mathrm{aE}}$ & $15.07^{\mathrm{bB}}$ & $14.13^{\mathrm{cC}}$ & $15.77^{\mathrm{aA}}$ & $13.13^{\mathrm{bCD}}$ & $13.20^{\mathrm{aD}}$ \\
\hline & 1.5 & $12.03^{\mathrm{aE}}$ & $16.20^{\mathrm{aA}}$ & $15.33^{\mathrm{bB}}$ & $15.97^{\mathrm{aA}}$ & $13.33^{\mathrm{bc}}$ & $12.07^{\mathrm{CD}}$ \\
\hline \multirow{4}{*}{$\mathrm{TSS} / \mathrm{TTA}^{1}$} & 0 (control) & $1.44^{\mathrm{aD}}$ & $5.09^{\mathrm{bC}}$ & $5.95^{\mathrm{bBC}}$ & $7.27^{\mathrm{CA}}$ & $6.64^{\mathrm{bAB}}$ & $7.01^{\mathrm{abAB}}$ \\
\hline & 0.5 & $1.44^{\mathrm{aD}}$ & $7.64^{a B}$ & $7.56^{\mathrm{aB}}$ & $9.01^{\mathrm{bA}}$ & $8.36^{\mathrm{aAB}}$ & $7.81^{\mathrm{aAB}}$ \\
\hline & 1 & $1.43^{\mathrm{aE}}$ & $4.21^{\mathrm{bD}}$ & $5.64^{b c}$ & $11.33^{\mathrm{aA}}$ & $6.48^{\mathrm{bc}}$ & $7.85^{\mathrm{aB}}$ \\
\hline & 1.5 & $1.43^{\mathrm{aE}}$ & $7.85^{\mathrm{aAB}}$ & $5.18^{\mathrm{bD}}$ & $8.89^{\mathrm{ba}}$ & $6.61^{\mathrm{bBC}}$ & $6.33^{\mathrm{bCD}}$ \\
\hline
\end{tabular}

Means followed by the same lowercase letter in the columns and uppercase in the rows do not differ statistically in the Tukey test at $5 \%$ probability. ${ }^{1}$ TSS/TTA: Ratio of total soluble solids and total titratable acidity.

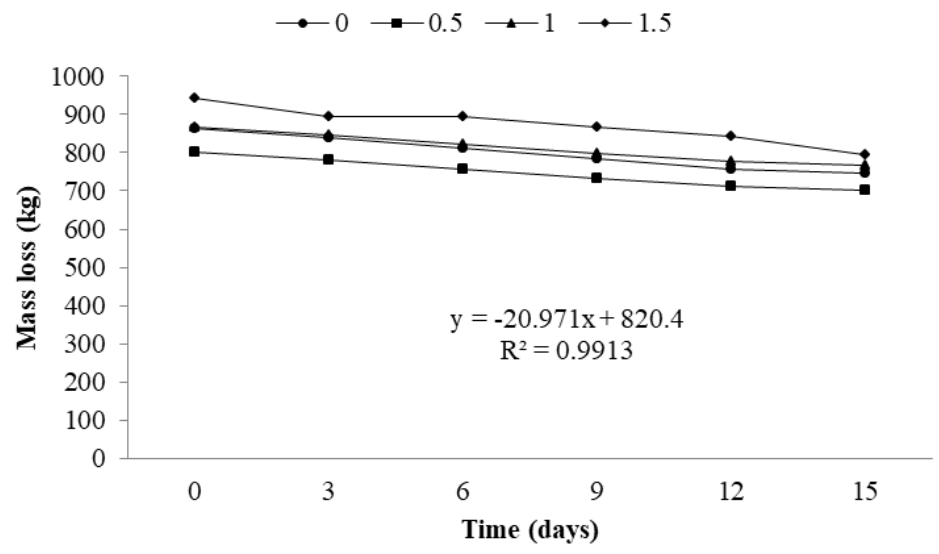

Fig 2. Graphical representation of Tommy Atkins mango fruits mass loss of during storage. 
Table 3. Tommy Atkins mango fruit peel color during storage.

\begin{tabular}{|c|c|c|c|c|c|c|c|}
\hline \multirow[b]{2}{*}{ Parameter } & \multirow[b]{2}{*}{$\begin{array}{l}\text { Concentration } \\
\text { moringa oil (\%) }\end{array}$} & \multicolumn{6}{|c|}{ Storage times (days) } \\
\hline & & 0 & 3 & 6 & 9 & 12 & 15 \\
\hline \multirow{4}{*}{ Luminosity L* } & 0 (control) & $59.87^{\mathrm{aA}}$ & $44.99^{\mathrm{aB}}$ & $54.32^{\mathrm{aAB}}$ & $52.22^{\mathrm{aAB}}$ & $47.65^{a B}$ & $52.45^{\mathrm{aAB}}$ \\
\hline & 0.5 & $44.25^{\mathrm{cA}}$ & $44.83^{\mathrm{aA}}$ & $49.32^{\mathrm{aA}}$ & $53.90^{\mathrm{aA}}$ & $51.77^{\mathrm{aA}}$ & $49.21^{\mathrm{aA}}$ \\
\hline & 1 & $54.35^{\mathrm{abA}}$ & $50.11^{\mathrm{aA}}$ & $53.35^{\mathrm{aA}}$ & $54.96^{\mathrm{aA}}$ & $52.67^{\mathrm{aA}}$ & $53.37^{\mathrm{aA}}$ \\
\hline & 1.5 & $49.37^{\mathrm{bcA}}$ & $49.54^{\mathrm{aA}}$ & $51.88^{\mathrm{aA}}$ & $54.68^{\mathrm{aA}}$ & $51.68^{\mathrm{aA}}$ & $52.56^{\mathrm{aA}}$ \\
\hline \multirow{4}{*}{ Intensity of red a* } & 0 (control) & $9.78^{\mathrm{aB}}$ & $25.13^{\mathrm{aA}}$ & $27.10^{\mathrm{aA}}$ & $24.44^{\mathrm{aA}}$ & $26.58^{\mathrm{aA}}$ & $23.76^{\mathrm{aA}}$ \\
\hline & 0.5 & $7.40^{\mathrm{abB}}$ & $29.44^{\mathrm{aA}}$ & $25.10^{\mathrm{aA}}$ & $25.29^{\mathrm{aA}}$ & $25.02^{\mathrm{aA}}$ & $25.81^{\mathrm{aA}}$ \\
\hline & 1 & $2.86^{\mathrm{bB}}$ & $27.38^{\mathrm{aA}}$ & $24.15^{\mathrm{aA}}$ & $23.91^{\mathrm{aA}}$ & $23.10^{\mathrm{aA}}$ & $21.88^{\mathrm{aA}}$ \\
\hline & 1.5 & $10.25^{\mathrm{aB}}$ & $25.97^{\mathrm{aA}}$ & $24.70^{\mathrm{aA}}$ & $22.94^{\mathrm{aA}}$ & $26.08^{\mathrm{aA}}$ & $22.72^{\mathrm{aA}}$ \\
\hline \multirow{4}{*}{$\begin{array}{l}\text { Intensity of yellow } \\
b^{*}\end{array}$} & 0 (control) & $41.60^{\mathrm{aA}}$ & $28.14^{\mathrm{abB}}$ & $40.18^{\mathrm{aA}}$ & $39.24^{\mathrm{aA}}$ & $35.92^{\mathrm{aAB}}$ & $43.19^{\mathrm{aA}}$ \\
\hline & 0.5 & $24.02^{\mathrm{CB}}$ & $24.67^{\mathrm{bB}}$ & $34.08^{\mathrm{aA}}$ & $38.12^{\mathrm{aA}}$ & $35.87^{\mathrm{aA}}$ & $36.37^{\mathrm{aA}}$ \\
\hline & 1 & $34.44^{\mathrm{abAB}}$ & $27.79^{\mathrm{abB}}$ & $37.35^{\mathrm{aAB}}$ & $34.60^{\mathrm{aAB}}$ & $38.62^{\mathrm{aA}}$ & $42.57^{\mathrm{aA}}$ \\
\hline & 1.5 & $31.06^{\mathrm{bcB}}$ & $35.99^{\mathrm{aAB}}$ & $37.40^{\mathrm{aAB}}$ & $41.98^{\mathrm{aA}}$ & $39.21^{\mathrm{aA}}$ & $40.55^{\mathrm{aAB}}$ \\
\hline
\end{tabular}

Means followed by the same lowercase letter in the columns and uppercase in the rows do not differ statistically in the Tukey test at $5 \%$ probability.

Table 4. Pulp color of Tommy atkins mango fruits during storage.

\begin{tabular}{|c|c|c|c|c|c|c|c|}
\hline \multirow[b]{2}{*}{ Parameter } & \multirow[b]{2}{*}{$\begin{array}{l}\text { Concentration moringa } \\
\text { oil (\%) }\end{array}$} & \multicolumn{6}{|c|}{ Storage times (days) } \\
\hline & & 0 & 3 & 6 & 9 & 12 & 15 \\
\hline \multirow{4}{*}{ Luminosity L* } & 0 (control) & $80.89^{\mathrm{aA}}$ & $77.43^{\mathrm{aAB}}$ & $79.58^{\mathrm{aA}}$ & $73.11^{\mathrm{aBC}}$ & $73.65^{\mathrm{aBC}}$ & $69.13^{a c}$ \\
\hline & 0.5 & $81.93^{\mathrm{aA}}$ & $77.29^{\mathrm{aAB}}$ & $76.83^{\mathrm{aB}}$ & $74.84^{\mathrm{aB}}$ & $73.79^{\mathrm{aB}}$ & $68.47^{\mathrm{ac}}$ \\
\hline & 1 & $83.72^{\mathrm{aA}}$ & $75.82^{\mathrm{aBC}}$ & $79.92^{\mathrm{aAB}}$ & $75.28^{\mathrm{aBC}}$ & $72.61^{\mathrm{aCD}}$ & $68.55^{\mathrm{aD}}$ \\
\hline & 1.5 & $82.62^{\mathrm{aA}}$ & $74.22^{\mathrm{aBC}}$ & $78.28^{\mathrm{aAB}}$ & $73.88^{\mathrm{aBC}}$ & $71.97^{\mathrm{aC}}$ & $71.29^{\mathrm{ac}}$ \\
\hline \multirow{4}{*}{ Intensity of red a* } & 0 (control) & $11.01^{\mathrm{aC}}$ & $15.58^{\mathrm{bB}}$ & $17.90^{\mathrm{aB}}$ & $19.22^{\mathrm{aB}}$ & $19.04^{\mathrm{aB}}$ & $23.88^{\mathrm{aA}}$ \\
\hline & 0.5 & $8.44^{\mathrm{aC}}$ & $16.81^{\mathrm{abB}}$ & $16.65^{\mathrm{aB}}$ & $19.50^{\mathrm{aAB}}$ & $19.12^{\mathrm{aAB}}$ & $21.31^{\mathrm{abA}}$ \\
\hline & 1 & $8.65^{a c}$ & $16.78^{\mathrm{abAB}}$ & $16.47^{\mathrm{aB}}$ & $18.68^{\mathrm{aAB}}$ & $19.12^{\mathrm{aAB}}$ & $20.94^{\mathrm{abA}}$ \\
\hline & 1.5 & $9.02^{\mathrm{aB}}$ & $20.00^{\mathrm{aA}}$ & $17.88^{\mathrm{aA}}$ & $20.38^{\mathrm{aA}}$ & $20.16^{\mathrm{aA}}$ & $19.96^{\mathrm{bA}}$ \\
\hline \multirow{4}{*}{$\begin{array}{l}\text { Intensity of yellow } \\
b^{*}\end{array}$} & 0 (control) & $57.28^{\mathrm{aC}}$ & $60.59^{\mathrm{bBC}}$ & $67.95^{\mathrm{aA}}$ & $67.42^{\mathrm{aA}}$ & $66.78^{\mathrm{aAB}}$ & $69.09^{\mathrm{aA}}$ \\
\hline & 0.5 & $56.36^{\mathrm{aB}}$ & $62.01^{\mathrm{abAB}}$ & $67.64^{\mathrm{aA}}$ & $67.00^{\mathrm{aA}}$ & $63.37^{\mathrm{aA}}$ & $66.97^{\mathrm{aA}}$ \\
\hline & 1 & $35.01^{\mathrm{bB}}$ & $63.22^{\mathrm{abA}}$ & $65.74^{\mathrm{aA}}$ & $66.58^{\mathrm{aA}}$ & $65.69^{\mathrm{aA}}$ & $67.73^{\mathrm{aA}}$ \\
\hline & 1.5 & $39.68^{\mathrm{bB}}$ & $67.68^{\mathrm{aA}}$ & $67.39^{\mathrm{aA}}$ & $68.19^{\mathrm{aA}}$ & $65.99^{\mathrm{aA}}$ & $66.91^{\mathrm{aA}}$ \\
\hline
\end{tabular}

Means followed by the same lowercase letter in the columns and uppercase in the rows do not differ statistically in the Tukey test at $5 \%$ probability.

induces the synthesis of new enzymes responsible for the carotenoid biosynthesis (Forato et al., 2015).

Bio-based coatings delayed the degradation of the pigments by making the bio-based coated fruits gain shine and remain with it. With the ripening process, fruit peel changed from green $-a^{*}$ to red $+a^{*}$. However, the yellow color prevailed over the red one. Color changes were delayed in the fruits by the application of $M$. oleifera oil-based coating, resulting in a delay in the ripening rate, possibly due to the delay in metabolic activities that led to a decrease in carotenoid synthesis (Bomfim et al., 2011).

According to Teodosio et al. (2018b), the coverings with Chlorella sp delayed the appearance of yellow in papaya. They found that the coatings made the fruits more opaque and delayed the synthesis and degradation of the pigments that cause the fruit to acquire shine, retarding the appearance of more accentuated shine. Non-enzymatic browning, destruction of pigments or other reactions that cause the color change of the product can affect the acceptance by consumers (Tan and Sulaiman, 2019).

Mango pulp is of great importance for the fruit industry as raw material, since it can be produced during harvest seasons, stored and reprocessed in more favorable periods or according to the demand of the consumer market. Table 4 shows that the pulp luminosity did not present positive interaction for the applied factors $(P>0.05)$, but the storage times had different effects on luminosity $(P<0.01)$. The same occurred for the intensity of red $a^{*}$. However, the yellow color characteristic of the mango pulp stood out from the red one, showing a positive interaction among the factors studied $(P<0.01)$.

For Damiani et al. (2013), the color may change according to the pulp storage time. They reported that all the color properties observed during one year of storage of frozen araça pulp rose increased. The color characteristic, despite not having a direct influence on the health conditions of the product, may be a factor that implies its rejection by the consumer market.

Moreira et al. (2013) studied the color of the Tommy atkins mango pulp. The values found were $65.80\left(L^{*}\right), 9.16\left(a^{*}\right)$ and $40.20\left(b^{*}\right)$. They are below the values verified in this study. The authors explain that the attribute that most calls the attention of the consumer is the color. This can be affected when food is thermally processed, with the degradation of 
pigments, such as carotenoids and chlorophyll, and enzymatic or non-enzymatic browning, as well as the $\mathrm{pH}$, acidity. Time and temperature of the process also have influence on this attribute.

\section{Materials and methods}

\section{Plant materials}

Tommy atkins mango samples were purchased at the Supply and Logistics Center in the city of Campina Grande, Brazil. The samples were selected according to ripeness, size and absence of disease or apparent damage. Then, they were packed in boxes and taken to the Laboratory for Processing and Storing of Agricultural Products at the Federal University of Campina Grande, Brazil.

To remove dirt and latex from the peel, the fruits were washed with running water and then sanitized in sodium hypochlorite solution at $200 \mathrm{ppm}$ for 15 minutes. Mangoes were submitted to the following treatments: moringa oil (Moringa oleifera) in concentrations of $0.5 \%(\mathrm{v} / \mathrm{v})+$ cassava starch for 2 minutes; $1 \%(\mathrm{v} / \mathrm{v})+$ cassava starch for $2 \mathrm{~min}$; $1.5 \%(\mathrm{v} / \mathrm{v})+$ cassava starch for 2 minutes and a control treatment without coating ( $0 \%)$. The oil was added to the $2.0 \%$ cassava starch solution by immersing the fruit for three minutes and then air drying it according to a methodology adapted from Lima et al. (2012). The starch solution was prepared using Manihot esculenta cassava. Tween was used as a thickening agent.

\section{Storage of Tommy atkins mango fruits}

After bio-based coating, fruits were stored at room temperature $\left(27^{\circ} \mathrm{C}\right)$ for 15 days. The following aspects were analyzed once every three days: $\mathrm{pH}$ by direct reading of the pulp homogenized in a digital pH meter bench (Brazil, 2008); total titratable acidity (TTA\%) by titration; total soluble solids (TSS\%) determined by refractometer, the results were expressed as ${ }^{\circ} \mathrm{Brix}$; TSS/TTA ratio by the quotient between the values of TSS and TTA; loss of mass was determined on a semi-analytical scale $(\mathrm{kg})$; color of the skin and pulp by using a digital colorimeter, in which the following parameters were determined: luminosity $L^{*} ; a^{*}$ transition from green ($\left.a^{*}\right)$ to red $\left(+a^{*}\right) ; b^{*}$ transition from blue $\left(-b^{*}\right)$ to yellow $\left(+b^{*}\right)$, according to methodology adapted from Palou et al. (1999).

\section{Statistical analysis}

The experimental design adopted was completely randomized in a $4 \times 6$ factorial scheme moringa oil in 4 concentrations: $0.5 \%(\mathrm{v} / \mathrm{v})+$ cassava starch; $1 \%(\mathrm{v} / \mathrm{v})+$ cassava starch; $1.5 \%(\mathrm{v} / \mathrm{v})+$ cassava starch and a control treatment without coating (0\%), during 15 days of storage $(0,3,6,9,12$ and 15 days), adding up to 24 treatments with three replications. The results were subjected to analysis of variance and the means compared by the Tukey test at $5 \%$ probability, using the statistical software ASSISTAT 7.7 (Silva and Azevedo, 2016).

\section{Conclusions}

Tommy atkins mango fruits with $M$. oleifera oil-based coating presented $\mathrm{pH}$ and ${ }^{\circ} \mathrm{Brix}$ within the established by the Brazilian legislation for mango pulp. The increase in the total soluble solids content and the reduction in total titratable acidity increased the TSS/TTA ratio at the end of fruit storage. The results of the mass loss indicate that the biobased coatings were efficient in the conservation of the fruits, especially, due to the low differences found in the values until the $12^{\text {th }}$ day of storage for the concentrations of 0.5 and $1 \%$. M. oleifera oil-based coatings delayed the degradation of the pigments, making the bio-coated fruits gain shine and remain with it. $M$. oleifera oil-based coating of 0.5 and $1 \%$ added to cassava starch provides a 12-day shelf life when stored at room temperature $\left(27^{\circ} \mathrm{C}\right)$.

\section{Acknowledgements}

The authors thank the Federal University of Campina Grande and the Federal Institute of Paraiba for their support in the study. We also thank the Agricultural Products Processing and Storage Laboratory.

\section{References}

Abalaka ME, Daniyan SY, Adeyemo SO (2012) The antibacterial evaluation of Moringa oleifera leaf extracts on selected bacterial pathogens. Res J Microbiol. 2:1-4.

Assis OBG, Brito D (2014) Revisão: coberturas comestíveis protetoras em frutas: fundamentos e aplicações. Braz J Food Technol. 17:87-97.

Bomfim MP, Lima GPP, José ARS, Vianello F, Oliveira LM (2011) Conservação pós-colheita de manga 'Tommy Atkins' com 1-metilciclopropeno. Revista Brasileira de Fruticultura. 33:290-297.

Borges CD, Mendonça CRB, Zambiazi RC, Nogueira D, Silva EMP, Paiva FF (2013) Conservação de morangos com revestimentos à base de goma xantana e óleo essencial de sálvia. Bioscience J. 29:1071-1083.

Brazil (2000) Ministério da Agricultura e do Abastecimento. Instrução Normativa no 1, de 7 de janeiro de 2000. Regulamento técnico geral para fixação dos padrões de identidade e qualidade para polpa de frutas. Diário Oficial [da] República Federativa do Brasil, Brasília, DF.

Brazil (2008) Métodos químicos e físicos para análise de alimentos. Instituto Adolfo Lutz. 4.ed. Normas analíticas do instituto Adolfo Lutz. São Paulo. 1, 1020.

Chitarra MIF, Chitarra AB (2005) Pós colheita de frutas e hortaliças: fisiologia e manuseio. Lavras: UFLA. 785p.

Cortez-Vega WR, Piotrowicz IBB, Prentice C, Borges CD (2013) Conservação de mamão minimamente processado com uso de revestimento comestível à base de goma xantana. Semina: Ciências Agrárias. 34:1753-1764.

Cruz MES, Jardinetti VA, Ryche AGG, Simon JM, Cruz MJS (2011) Efeito de Moringa oleifera na qualidade de frutos de manga CV Tommy Atkins. Revista Cadernos de Agroecologia. 6:1-5.

Damiani C, Lage ME, Silva FA, Pereira DEP, Becker FS, Boas EVBV (2013) Changes in the physicochemical and microbiological properties of frozen araça pulp during storage. Ciência e Tecnolologia de Alimentos. 33:19-27.

Forato LA, Brito D, Rizzo JS, Gastaldi TA, Assis OBG (2015) Effect of cashew gum-carboxymethylcellulose edible coatings in extending the shelf-life of fresh and cut guavas. Food Packag Shelf Life. 5:68-74.

Ghodsi R, Sadeghi HM, Asghari G, Torabi S (2014) Identification and cloning of putative water clarification genes of Moringa peregrina (Forssk.) Fiori in E. coli Xl1 blue cells. Adv Biomed Res. 27:3-57. 
Kumar P, Sethi S, Sharma RR, Srivastav M, Varghese E (2017) Effect of chitosan coating on postharvest life and quality of plum during storage at low temperature. Scientia Horti. 226:104-109.

Lima AB, Silva SM, Rocha A, Nascimento LC, Ramalho FS (2012) Conservação pós-colheita de manga 'Tommy Atkins' orgânica sob recobrimentos bio-orgânicos. Revista Brasileira de Fruticultura. 34:704-710.

Lima MAC, Silva SM, Oliveira VR (2018) Umbu - Spondias tuberosa. Exotic Fruits. 1:427-433.

Lin L, Gu Y, Cui H (2019) Moringa oil/chitosan nanoparticles embedded gelatin nanofibers for food packaging against Listeria monocytogenes and Staphylococcus aureus on cheese. Food Packag Shelf Life. 19:86-93.

Mali S, Grossmann MVE, Yamashita F (2010) Filmes de amido: produção, propriedades e potencial de utilização. Semina: Ciências Agrárias. 31:137-156.

Mannozzi C, Cecchini JP, Tylewicz U, Siroli L, Patriganani F, Lanciotti R (2017) Study on the efficacy of edible coatings on quality of blueberry fruits during shelf-life. LWT-Food Sci Technol, 85:440-444.

Moreira C (2013) Respiração. Rev Ciênc Elem. 1:1-5.

Moreira TB, Rocha EMFF, Afonso MRA, Costa JMC (2013) Comportamento das isotermas de adsorção do pó da polpa de manga liofilizada. Revista Brasileira de Engenharia Agrícola e Ambiental. 17:1093-1098.

Oliveira LM, Alves KA, Teodosio AEMM, Morais FA (2018) Postharvest of tommy atkins mango submitted to coating of Chlorella sp. J Agric Sc. 10:225-233.

Onias EA, Rocha RHC, Lima JF, Onias EA, Furtunato TCS (2016) Qualidade pós-colheita de manga "Tommy Atkins" orgânica tratada com biofilmes enriquecidos com Spirulina platensis. Científica. 44:286-293.

Onias EA, Teodosio, AEMM, Bomfim MP, Rocha RHC, Lima JF, Medeiros MLS (2018) Revestimento biodegradável à base de Spirulina platensis na conservação pós-colheita de goiaba Paluma mantidas sob diferentes temperaturas de armazenamento. Revista Ciências Agrárias. 41:849-860.
Othman AS, Ahmed N (2017) Antibacterial effect of the ethanol leaves extract of Moringa oleifera and camellia sinensis against multi drug resistant bacteria. J Pharmacokinet Phar. 13:156-165.

Palou E, Cánovas GVB, Chanes JW, Swanson BG (1999) Polyphenoloxidase activity and color of blanched and high hydrostatic pressure treated banana puree. J Food Sc. 64:42-45

Pereira GS, Machado FLC, Costa JMC (2014) Aplicação de recobrimento prolonga a qualidade pós-colheita de laranja 'Valência Delta' durante armazenamento ambiente. Revista Ciências Agrárias. 45:520-527.

Pimentel JDR, Souza DS, Oliveira TV, Oliveira MC, Bastos V, Castro AA (2011) Estudo da conservação de mamão Havaí utilizando películas comestíveis a diferentes temperaturas. Scientia Plena. 7:1-6.

Sanches AG, Silva MB, Moreira EGS, Cordeiro CAM (2017) Fontes de amido e temperatura de armazenamento na manutenção da qualidade pós-colheita da pitaya de polpa vermelha. Colloquium Agrariae. 13:41-54.

Silva FAS, Azevedo CAV (2016) The Assistat software version 7.7 and its use in the analysis of experimental data. Afr J Agric Res. 11:3733-3740.

Tan SL, Sulaiman R (2019) Color and rehydration characteristics of natural red colorant of foam mat dried Hibiscus sabdariffa L. powder. Int J Fruit Sci. 20:89-105.

Teodosio, AEMM., Onias, EA., Oliveira, LM., Rodrigues, MHBS., Ribeiro, J.A., Queiroga, TB. (2018a). Influence of different coatings on quality and shelflife of guava under different storage temperatures. J Exp Agric Int. 26:1-10.

Teodosio AEMM, Rocha RHC, Lima JF, Onias EA, Ferreira APN, Santos BGFL (2018b) Effect of the biodegradable coatings the base on microalgae and oil of the seed of the pomegranate in the conservation powder-crop of the papaya Golden'. J Agric Sc. 10:367-377.

$\mathrm{Xu} \mathrm{D,} \mathrm{Qin} \mathrm{H,} \mathrm{Ren} \mathrm{D} \mathrm{(2018)} \mathrm{Prolonged} \mathrm{preservation} \mathrm{of}$ tangerine fruits using chitosan/montmorillonite composite coating. Postharvest Biol Tec. 143:5057.

Zhao Y (2019) Edible coatings for extending shelf-life of fresh produce during postharvest storage. Encyclop Food Sec Sustain. 2:506-510. 